Issledovatel'skiy Zhurnal Russkogo Yazyka i Literatury, Vol. 9, Issue 2, 2021, Pp: 225-244

DOI: 10.52547/iarll.18.225 DOR: 20.1001.1.23452498.2021.9.2.12.0

Article No.: 18.121.20212.225244

Scientific Article

\title{
In The Hermeneutical Circle of an Itinerant Scientist
}

\author{
Korneeva Lyudmila Nikolaevna ${ }^{1}$ * \\ Poet, literary critic, \\ Republic of Crimea, Russia.
}

(date of receiving: May, 2021; date of acceptance: July, 2021)

\begin{abstract}
The article, based on the material of travelogues of Philology Professor Tatyana Alexandrovna Koshemchuk (St. Petersburg), examines the concept and hermeneutics palette of spatial research of a scientist-traveler as an experience of modern pilgrimage. It is shown that the travel routes are built on the stream of the anthroposophical history of post-Atlantic cultures, reflected in the landscapes of modern Iran, Egypt, Greece, Italy, Germany and Russia. The basis of creative method of spatial cognition in travelogues is the hermeneutic circle as the interaction of the integrity of the whole concept (prediction) and its parts, facts and specific observations. The succession of the author's travel practice with the system of world knowledge of the great geopoet Maximilian Voloshin is emphasized; the evidence about the role of Russia and of the Crimea in the continuity of world cultural development is gathered together, indicated in the observed travelogues, resulting from the scientific concept of the researcher.
\end{abstract}

Keywords: Spirituality of Man and Space, Geopoetics as Intelligent Contemplation, Hermeneutics, Travelogue, Crimea, Maximilian Voloshin.

1. E-mail: pln-road@yandex.ru * Corresponding author 
Issledovatel'skiy Zhurnal Russkogo Yazyka i Literatury, Vol. 9, Issue 2, 2021, Pp: 225-244

DOI: $10.52547 /$ iarll.18.225 DOR: 20.1001.1.23452498.2021.9.2.12.0

Article No.: 18.121.20212.225244

\title{
В герменевтическом круге странствующего учёного
}

\author{
Корнеева Людмила Николаевна ${ }^{1}$ * \\ поэт, литературовед, \\ Республика Крым, Россия. \\ (дата получения: май 2021 г.; дата принятия: июль 2021 г.)
}

\begin{abstract}
Аннотация
В статье на материале травелогов Т.А. Кошемчук рассматривается концепция и герменевтическая палитра пространственного исследования учёногопутешественника как опыт современного паломничества. Показывается, что маршруты путешествий выстраиваются в русле антропософской истории постатлантических культур, которые отражаются в ландшафтах современных Ирана, Египта, Греции, Италии, Германии и России. Основой творческого метода пространственного познания в травелогах является герменевтический круг как взаимодействие целостности концепции (предзнания) и частей ее, фактов, конкретных наблюдений. Акцентируется преемственная связь авторской тревелпрактики с системой миропознания великого геопоэта Максимилиана Волошина (1877-1932); собираются воедино обозначенные в наблюдаемых травелогах свидетельства о роли России и Крыма в непрерывности мирового культурного развития, вытекающей из научной концепции исследователя.
\end{abstract}

Ключевые слова: Духовность Человека И Пространства, Геопоэтика Как Умное Созерцание, Герменевтика, Травелог, Крым, Максимилиан Волошин.

1. E-mail: pln-road@yandex.ru * Ответственный автор 


\section{Введение}

О существовании чётко оконтуренной тревел-грани в научном творчестве Т.А. Кошемчук стало возможно говорить, когда вышла в свет её третья книга единой серии «о понимающих проникновениях в различные творческие явления» (Кошемчук 2015; Кошемчук 2018; Кошемчук 2020), включающей путевые заметки под рубрикой «ИЗ УВИДЕННОГО» (которые жанрово определяются ныне как травелоги), рождённые общением с различными географическими локусами земли как с многозначными ландшафтами истории культуры и духовности - посредством созерияания.

Результат путешественнических разысканий Татьяны Кошемчук может быть осознан в полной мере лишь читателями, участливо прошедшими вместе с автором по маршрутам её травелогов. Но нам представляется очень важным показать смысловые маркеры для их целостного восприятия.

Определяя исходные позиции для продуктивности своих наблюдений, заметим, что каждый путешественник проницает географический локус на такую глубину, которую может осилить его геопоэтическое видение, понимаемое, в первую очередь, как способность к сущностному постижению пространства. Думается, что геопоэтическая высота научных разысканий Т.А. Кошемчук изначально определилась в процессе пристального вникновения в творчество великого геопоэта М.А. Волошина, во время работы над диссертацией «Сонеты Максимилиана Волошина» (Кошемчук 1990): исследуя заземлённые в «вечном Коктебеле» произведения великого киммерийца, устремлённые к таинственным началам мира, полные гностических и антропософских проницаний реального места земли, Татьяна Кошемчук получила прививку основательного взгляда на пространство и время. Судя уже только по оформившимся свершениям, в научной судьбе Татьяны Кошемчук случилось примерно то же, что и у Волошина: творчески освоив, в назначенное 
время, антропософскую матрицу мировосприятия, она смогла выстроить собственную программу и методологию познания мира, утвердиться в духовных основаниях общения с пространством через созерцание. Квинтэссенцией пространственных осознаний Татьяны Кошемчук видится её глубокомысленное умозаключение о «феноменологии созерцания», которое «всегда связано в своей глубине с ощущением Бога, а в конечном итоге устремлено к жизни вечной и к соприкосновению со сверхчувственным, <..> созериание дарит поэтам и философам, своим адептам-мученикам Красоть - и художественные прозрения, и мистические озарения, и мыслительные проникновения...» (Кошемчук 2020а. 34). Как видим, современный учёныйпутешественник следует по испытанному гётеанскому пути познания природы, земли, пространства - через духовное сопричастие, сопереживание - и по волошинскому пути понимания миссии художника и исследователя: выявлять и озвучивать вести немой земли, быть её «глазами и устами».

И все травелоги Т.Кошемчук, в первую очередь, являются ярким подтверждением, что лишь сознание, разбуженное сильной «захватывающей» - эмоцией, может постичь «праидею созерияемого». Отмечая состояние экстатической душевно-телесной подчинённости путевым впечатлениям, исследователь видит в путешествиях энергию для преображения их в паломничество.

\section{Основная часть}

Уже только познакомившись в оглавлении указанной трилогии с маршрутами путешествий под рубрикой «ИЗ УВИДЕННОГО», можно интуитивно почувствовать неслучайность и соположенность их выбора. Хоть автор изначально и не декларирует свой выбор как некий стратегический замысел, но однажды, в последней из указанных книг, обозначает: «...я вновь обращаюсь к Штейнеру <...> с его всеобъемлющей панорамой человеческой 
истории, в ходе которой созидается человеческое “Я” как смысл земного бытия, и я заново читаю о древнеперсидской эпохе, следующей за индийской, а далее продолженной египетской, затем греко-римской и уже нашей, пятой, европейской культурой...» (Кошемчук 2020. 82-83). То есть учёныйпутешественник, отмечает свою онтологическую сосредоточенность на локусах земли, неразрывно связанных с культурными эпохами, явленными на пассионарном взлёте проживавших там народов. Иначе говоря, декларирует как объект своего научного интереса вселенские пики культурной истории человечества, череда которых, по Штейнеру, знаменует также этапь в развитии самосознания человека. Их связь с маршрутами путешествий автора травелогов становится тотчас очевидной, и они сразу же выстраиваются в определённом порядке и складываются в некое единство, даже в неразъёмную целостность - выразительный страннический эпос, в котором внимательный читатель, по мере освоения текстов, узрит устойчивый геопоэтический мост к великим вериинам культуры и духа:

1. Встреча с Древней Персией

2. Египетские письма

3. Итальянские письма

4. Путешествие по долине Рейна

5. К «Итальянским письмам»: загадка барокко

6. О Духе Крыма

Думается, что авторский замысел такого путешествия, возникнув однажды, никогда не покидал автора записок: и вот уже не одно десятилетие, как путешествующий учёный, она собирает пыльцу смыслов с цветов культур, расцветших в различных краях земли в назначенное для них время, антропософски представляя это шествие культур как историю человеческого «Я», в подробностях выявляя, как выковывалась духовность - высшая ценность христианской культуры. 
Сложность путешествия по намеченной целевой программе совершенно очевидна: очень трудно представить место на земле, где бы древность сохранилась в неизменности, хотя бы в своих наиболее временеустойчивых архитектурных - свидетельствах. В лучшем случае (чаще всего в интересах туристов), сохраняются древние развалины городов и крепостей, а чаще всего материальная плоть эпохи полностью уходит в незримые слои бытия, от многих из них ныне сохранились лишь загадочные знаки и символы, которые едва просвечивают канувшими в бездну эпохами. Как, не имея достаточной фактологической базы, проникнуться их смыслами?.

Очевидно, что здесь нужны иные методы, основанные не на документах и артефактах, а на понимании и интерпретации феноменов культуры. Такие методы понимающего познания утвердились ныне в науке как герменевтические. Современная культурология выработала также представление о механизме понимающего познания - герменевтический круг познающего, - основой которого является последовательное взаимодействие в сознании человека представлений о целостности явления (процесса, текста) и о его связях с частями этой целостности, другими словами, взаимодействие теоретического предзнания о наблюдаемом явлении и интерпретации каких бы то ни было фактов о нём. Современная культурология доказывает, что герменевтический опыт объективен: для того, чтобы нечто понять, его необходимо объяснить, и наоборот. В контексте этих понятий, травелог неотъемлемая часть пространственного познания, потому что он фиксирует не только теоретическое предзнание путешественника о созерцаемом, но и добытое им в герменевтическом круге понимание: от теории к факту и наоборот. Это очень сложная грань культурологии, и как ими владеет Татьяна Кошемчук, можно судить по её собственным гносеологическим меткам в травелогах: 
«Так было часто: некая мысль живёт в моей памяти, чья-то дорогая мне мысль, - и я обретаю в том или ином своём наблюдении подтверждение ей, и она получает вес и объём, я переживаю её вдвойне u - присваиваю её по праву, дав ей моё собственное, порой иное звучание...» (Кошемчук 2015. 190).

«...речь пойдёт, по преимуществу, о том, что я вижу своими глазами, что открывается в непосредственном созериании, становится очевидным, о том, что отражается в чувстве и стремится $к$ своей осмысленности» (Там же. 189);

«Это чувство, рожденное созериянием, не поэтично, не вдохновенно, но оно... поразительно! - и порой тягостно, как отдаёт тяжестью всё ощущаемое, что не поддается освещуению светом сознания» (Кошемчук 2020. 82).

То есть историческое знание, добытое Штейнером с помощью ясновидения и сведённое им в теоретическую парадигму истории послеатлантической культуры человечества, современный исследователь выверяет и оживляет средствами умного созерцания сохранившихся знаков древних эпох.

Как видим, антропософская система воззрений позволила Татьяне Кошемчук, как и Волошину, «вспоминать историю человечества из себя», «читать» её «в безднах своего бессознательного» (Волошин 1904). И вот её проясняющее высказывание об этом: «В антропософских книгах нахожу я нужное для понимания и моего захватывающего чувства не озаряемой моим сознанием древности, и для захватывающего ощущения огромности всего канувшего в незапамятные бездны прошлого» (Кошемчук 2020. 85).

И, как резюме интеллектуальных усилий путешественника-учёного в данном русле - вот это ключевое высказывание: «Это оказалось необходимо: уметь восстановить, увидеть утраченное навсегда...» (Кошемчук 2015. 198). 
В поисках Древней Персии Татьяна Кошемчук совершила реальное путешествие в Иран. И хоть сегодня «вид иранского жизненного пространства не одаривает щүедростью, ничего ияветущеего, пыщного, повосточному колоритного», но целенаправленность проницательного созерцания сотворила чудо... И вот пустыня Ирана открылась ей местом рождения незыблемого основания человеческого сознания: «...древний - после атлантической катастрофы - зороастризм выковывал здесь полярности душ, впервые проживающих растяжку <..> между духами добра и духами зла - эту грозную и суровую правду о мире, впервые осознанную, выраженную, проповеданную и навсегда утвержденную в анналах человеческих душ. И это персидское древнее, неисчислимо древнее, <..> живет в каждом из нас - с тех пор, когда и мы в каком-то из звеньев великой Цепи - в этих пустынях проживали огненные полярности борьбы светлых и темных духов, с первой отвагой становясь на сторону светльх, ради Аиу - мировой гармонии, именно здесь впервые открытой в намем земном мире. Именно это прачувство восходит в сознание в этих волнах цввета темной охры, золотящейся на пылающем солнце, оно задает основной тон переживанию глухой персидской древности» (Кошемчук 2020. 82).

В современном мусульманском облике Ирана исследователем выявлены мерцающие смыслы немногих, но выразительных знаков эпохи зороастризма: и в сохранении культурных аллюзий великого арийского прошлого - старых башен, колонн дворцов, львов, воинов, крылатых быков; и в существовании мавзолеев великих поэтов, как в Ширазе; и в живости традиции изображения человеческих лиц. Даже в том, что мусульманство в Иране имеет особенную форму - шиизма, усматривается смягчающая сила древней культуры, «мудрость и свет из небесной Персии» (Там же. 95).

В других травелогах, не менее обстоятельно и зримо воссозданы последующие этапы в развитии человеческой культуры и духовности. Все они, 
по сути, - энциклопедически обоснованные герменевтические толкования. В рамках краткой статьи мы имеем возможность лишь акцентировать их важнейшие смыслы.

В «Египетских письмах» Т.А. Кошемчук можно расслышать культурологическую стереофонию духовных кодов, как будто не поддающихся пониманию современного человека: «Сама культура здесь была не для жизни - для посмертия... Для посмертия немногих и исключительньх для посвящённых, для фараонов < ... Они, властители этих подземных путей и залов, сходили сюда в незабвенность своего земного бытия - вечной своей телесной, мумифицированной ипостаси, созерияая и оставленное земное, прекрасно изображенное на стенах, и собственную живую, идеально похожую статую, постигая отделённость своего духа в отдельности телесной, - тем самым отрываясь от общего и нерасчленённого человеческого существа. И когда в эти долгие египетские тысячелетия душа возвращалась на землю вновь, уже как особость, готовая к миссии, в теле фараона или жрецุ, - то творила всё ту же культуру, всё то же царство, тянущееся нескончаемой длительностью истории и долгой лентой Нила в узком коридоре долины, окаймлённой жёлтыми горами, под взорами всё тех же звероголовых богов. Так выковывались отдельные богоподобные личности, которые теперь смотрят на нас, поверх нас, в свою вечность - поразительно отрешённым, даже надменным взглядом своих бесчисленных статуй <..> До Христа ещеё далеко, то есть и до - собственно человека. <..> И - даже фараонь, созидатели гробнич и пирамид ради своей будущей человечности, своей сверхчеловеченостью обязаны в них обитающему иному и высшему. Огромность их восходящих усилий дана в пирамидах...» (Кошемчук 2020. 3242).

Все эти могучие и властные колонны храмов, пирамиды, статуи фараонов, сфинксы Древнего Египта расшифрованы путешествующим учёным как 
«мощьь души и твёрдость стояния в духе древних египтян». Ключевая же авторская мысль в том, что «эта древнеегипетская культура, как голова фараона Хефрена, ещё не несёт в себе индивидуальность и самобытность личности в нашем смысле, но многомудрость и самоотрешённость сверхчеловеческой души посвящённого» (Там же. 52). И как итог: «Новая египетская культура души на пути к человеческому “Я” оставила в прошлом персидскую дуальность света и тьмы и впервые обрела <..> многогранность» (Там же. 53).

Духовные знаки древнегреческой цивилизации наблюдались учёным, путешествующим по мировым культурам, не только на афинском акрополе, но и в итальянском Пестуме, сицилийском Агридженто, тунисской Дугге, и тоже - через слои позднейших культур... И снова наблюдаем, как избранный ракурс воззрения позволяет учёному сквозь внешний облик места видеть все, даже самые глубокие и древние временные слои этого локуса... Так, в современном Неаполе, хоть и сохранившем древнее греческое имя (Неаполис органическая часть Эллады), но где в облике города не сохранилось никаких зримых следов исконной греческой красоты (воплощённой когда-то в архитектурном совершенстве храмов, статуй и колонн), созерцающая энергия странника по мирам всё же находит средоточия далёкой и угасшей культурной эпохи - всматриваясь и проникаясь влиянием западной окраины города - Кумами, где когда-то в языческом капище прозвучало пророчество древней Кумской сивиллы о приближении христианского перелома мира...

Всё это насыщенное смыслами живописание путешествий даёт понимание древнейшей, дохристианской истории как взрастания духовности человека в неразрывной цепи цветущих культур. И в знаках, оставленных этими культурами, можно рассмотреть предчувствие Христа. У персов - в образе грядущего Спасителя, предсказанного Зороастром; у египтян - в потаённом боге Амоне, у древних греков - в образе неведомого Бога... 
В итальянских маршрутах путешествий особое внимание нашего странствующего учёного приковывает Рим. В читательскую душу он тоже заходит «по свету первичного отражения в чувстве» - как шедевр дивного схождения множества непреходящих культурных достижений человечества: «Не в этом ли тройном свете сошедшихся здесь эпох - античности, Средневековья и Возрождения - покоится теперешний Рим, не он ли светит в самом его воздухе?» (Кошемчук 2015. 201).

Культурологически обострённый взгляд учёного прослеживает и в современном облике Рима едва заметные следы далёкого напряжённейшего столкновения прекрасного и обречённого языческого и нового, христианского: «Глубока была пропасть, возникшая между высокой культурой языческого Рима и духом новой эпохи, которой просто нечего было делать со всем этим оставшимся прекрасным добром, глубочайше чуждым <..> этим смиренным последователям галилейской простотьл.<..>.Эта страшная красота, к ужасу христианина, отзывается в душе могуществвенно, властно - это переживание неизбежно для каждого, кто всматривается в римские остатки с порога древней базилики. < .. > Христианин, со своим Богом в душе, идущий по развалинам язычества, по римским руинам, мыслим - только с опущенными невидящими глазами, с отремённой дущой. <..> Bыход у христианской религии был только один - создать более высокую эстетическую форму, победить и здесь» (Там же. 206-208).

В записках Т.A. Кошемчук, опять же на основании зримого, прослеживается этот варварский процесс уничтожения былой культуры, от которой «отозвана духовная санкиия». Но, параллельно ему, выявляется и процесс созидания новых культурных форм, к XV веку давших «мощный противовес, новую великую красоту», в которой очевидно «величайшее деяние римского духа»: «Высокое Возрождение есть новая страница в истории человеческого духа, о которой рассудочная античность <..> не имела ни малейшего понятия. <..> Этот опыт навсегда оставил в прошлом всю 
натужную холодную мудрость < ..> и саму душу гармонического античного мира. <..> Этот новый свет самосознания в высший час его истории сходит как ещуё один божественный дар, как открывщаяся возможность стать «Я». <..> Тяжель божественные дары и велики задания: этот новый человек может создать в себе истинную Рафаэлеву гармонию, обуздать сложность - самообладанием, осветить христианским светом. Новый человек - уже не рассудительный Марк Аврелий, рядом с которым, с его рассудочной и бескрылой мыслью, с его благородной мёртвой маской, встаёт Леонардо живой и трагический, ибо теперь уже есть опыт встречи человека с Богочеловеком...» (Там же. 195, 225-226).

Так, шествуя страницами травелога Т.А. Кошемчук по Риму, оживляющего римские форумы и мраморные лестницы, античные развалины и раннехристианские базилики, входя в католические храмы, созерцая рафаэлевскую живопись, приближаемся к пониманию обобщений, которые дают обзор вселенского движения человека к самосознанию своего духа: «Наш Творец посылает нам великие дары нечасто, и высокие свои воздействия в созидании человеческих душ силь небеснье собирают в одной точке на краткий срок, как будто косность материала, наша человеческая, не позволяет широкого охвата, и редкими, редкими остаются те пики, где творится новое в душе, а значит, в искусстве и в мысли, а потом уже излучается вщирь, в культуру - и таковыми были Древняя Эллада на несколько десятилетий, потом золотой век Рима, наконец, взрыв искусства Италии на рубеже XV и XVI веков...» (Там же. 208-209).

В римском травелоге явственнее всего проступает герменевтический круг автора - от понимания в целом процесса духовного развития человека до выявления смысла его христианского этапа.

Особенность исследовательских маршрутов Т.А. Кошемчук по местам утверждения европейской культуры через христианство - в том, что они 
проходят не по странам, а по сохранившимся знакам европейских «духовных потоков» разных культурных эпох. Так, странствуя по долине Рейна, она обращается не просто к достопримечательностям, а к местам, где утверждалось христианство, где творилась европейская духовная история. Осторожно прикасаясь к пространствам, освящённым охранительным духом церквей и монастырей, служители которых улавливали глубинные потребности европейских душ и отзывались на них, исследователь выявляет духовные корни европейской цивилизации.

В этом путешествии Татьяна Кошемчук получает сама и оформляет в травелоге наглядное представление об обретении Европой «мощңной духовной брони» для более чем тысячелетнего дерзновенного исторического творчества, воссоздаёт конкретный путь Средневековой Европы к предустановленному: быть историческим мостом между имперским духом Рима и двумя его последующими трансформациями: западной, в Священной Римской империи германской нации, и восточной - Российской империи.

Путешествия Татьяны Кошемчук по Крыму тоже множественны и целенаправленны. И хоть пока они не оформлены в какие-либо отдельные тревел-произведения, но эти накопления реального крымского странничества дали ей поразительную свободу суждений и умозаключений о Крыме, это осязаемое представление его физической плоти в онтологическом контексте всемирной истории и культуры: «Нельзя говорить о крымской культуре как мы говорим о русской или немецкой, но это и не областной локус внутри русской или европейской культурной целостности. Его положение особенное $<\ldots>$ Крымское культурное пространство, с европейской точки зрения, периферийный феномен, с античности - задворки мировой истории, самылй край средиземноморского мира, его малая форма - но и в малой форме можно творить шедевры, особенно если отделить его от материнского лона $u<\ldots>$ привить к иному древу...» (Кошемчук 2020. 258). 
Несомненно, речь идёт о «древе России». И в этот момент чтения вдруг проясняется, что именно вселенский контекст знаковых пространств позволяет путешествующему исследователю осознать особость и далеко не региональную значимость давно выделенного сердцем крымского локуса земли и передать это осознание читателям. К пониманию столь непростого умозаключения автор приводит читателя последовательно - через идею соположенности России с цивилизациями, которые исследованы в процессе мирового путешествия, как уже явленные этапы культурного восхождения человечества. Образ России не однажды всплывал в мыслях Татьяны Александровны, рождённых в чужих землях и иных странах, во время её целенаправленного путешествия. И вот, наконец, открыто и цельно, проговаривается глубоко осознанная ею антропософская весть о России, органично связанная с идеей о пяти уже воплощённых этапах штейнеровской всеобъемлющей панорамы постатлантической истории человечества: «..Россия - страна молодая <... . Нама культурная молодость СВОЕ СЛОВО скажет в будущем Шестой эпохи, когда «Я» человека обратится к

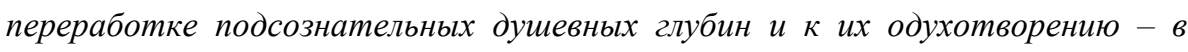
этом дальнейший путь человеческого «Я»...» (Кошемчук 2020б).

Именно в таком обширном историко-культурном контексте, в соположенности культур Европы и России, следующее восторженное высказывание Татьяны Кошемчук о Крыме воспринимается как выстраданное знание, проникнутое любовью: «Крым - уникален в русском мире. < ..> И если у нас в России нет отстоянной в тысячелетиях духовной работы, нет древности как органического наследства, то КРЫМ ВСЕ ЭТО В СЕБЕ ИМЕЕТ! - Он распахнут в европейский период с самого его начала - в венецииаскую и генуэзскую Италию - связан с местом главного духовного свершения XV века. <..>. Крым распахнут и в четвертый, античный культурный период, с ним Крым связан глубинно, будучи органической частью 
античной культуры, пусть её дальней периферией, - но он несёт в себе импульс подлинной античности, отражённой в цикле мифов и преданий, в истории греческих колоний. И ещё глубже: следы древней атлантической мудрости ощутимы здесь в скифском наследии, в киммерийских степях, дух которых остро чувствовал Волошин <..>. Так русская тоска по всемирной культуре влечёт к Крыму неодолимо, Крым - ВРАТА во всемирность для русской души, разливающейся по своим огромным равнинам. <... . И потому, привитый к древу России в XVIII веке Крым, этот боковой побег иного, древнейтего древа, сросся с русским миром органически, отвечая насущнейшей духовной потребности русской души и служа ей, и связь эта неразрывна. КРЫМ НАШ, прежде всего духовно и сущиостно...» (Кошемчук 2020б).

Т.А. Кошемчук, зная и любя плоть Крыма с молодости, с далёких страннических подходов смогла увидеть его вселенскую духовную самоценность, и её травелоги о путешествиях по миру неожиданно подвели к теоретико-философскому осмыслению Крыма и его культурной истории.

И здесь всплывает ещё один фактор, вообще проясняющий возможность подобного реального путешествия к местам земли в разные, - даже незапамятные прошлые и трудно представимые будущие - времена. Оно оказалось по плечу именно русскому исследователю, заряженному необъятностью и многоликостью российского пространства, и потому генетически приспособленному высвобождать пространство от времени. И вот в культурном ландшафте современного Ирана, Египта, Греции, Италии, Германии, Франции, России и Крыма Т.А. Кошемчук удалось опознать, осмыслить и выстроить в эксклюзивные травелоги увиденные следы на пути поэтапного восхождения человеческого самосознания, восчувствовать знаки культурного взрастания человека - его духом. В итоге, учёному открылось таинственное - исключительно силой мысли и чувства. И это отнюдь не 
мистика, но овладение современными инструментами познания, умное созерцание и, по слову Р. Штейнера, «серьёзная научная мыслительная работа» (Штейнер 1991.7).

Нигде не сохранились прямые свидетельства о том, как развивалось в человеке осознание духовности человека и мира, но именно это - в хронотопе каждой из цивилизаций - стремится рассмотреть путешествующий учёный Т.А. Кошемчук, и лишь владение методом понимающего созерцания открывает ей путь прозрения невидимого. В итоге, в герменевтических откровениях статей ИЗ УВИДЕННОГО, за знаками и символами, нам открываются смыслы и ценности целых эпох. При этом эпохальные события, в которых вызревала человеческая духовность, действительно предстают в описаниях единой цепью и выглядят частями единого сюжета, а его смыслообразующей идеей видится некое вышнее задание народам мира выразить средствами культуры непостижимость божественных идей.

\section{Заключение}

Итак, на пересечении геопоэтического видения и герменевтической методологии, в антропософской озарённости исследования Татьяне Кошемчук удаётся объективировать свои переживания в общении с пространством и своё оригинальное видение созерцаемых локусов. И теперь становится несомненным, что в глубине программы её путешествий было именно паломничество, то есть, устремление не только к обозрению пространств и познанию их культурно-исторического существа, но и к восприятию их незримых духовных излучений.

Представленные травелоги Т. Кошемчук несут в себе черты различных форм литературного письма. Авторская концепция путешествия отзывается и сакральной традиции древнерусских книжников, целью которых были хождения духовной направленности, и целеполаганию философского 
путешествия, с гомеровских времён устремлённого к познанию основ человеческого бытия, и предметности документального очерка, рождающегося на основе реального общения с географическими локусами. И в то же время травелоги Т.А. Кошемчук имеют своё собственное, неповторимое лицо. В обобщающем видении, они представляют собой впечатляющую панораму познания, где путешествующий учёный, вооружённый концепцией вселенского развития культуры и духа, а также эффективной современной методологией, движется к убедительным образам прошлого, гётеански собирая в цельные картины свои ощущения, чувства, догадки, аллюзии, отрывочные прозрения... Но ведь это именно тот путь, воодушевляющий опыт которого - и в художественном творчестве, и в историософских размышлениях - оставлен выдающимся дознавателем земных и космических тайн Максимилианом Волошиным. И, как теперь понимается, это единственный путь к истинному знанию о необратимых временах.

\section{Литература}

1- Антология «M.А.ВОЛОШИН: PRO ET CONTRA» (2017). (Личность и идейнохудожественное наследие М.А.Волошина в оценках отечественных писателей, мыслителей, исследователей) // Сост., вступ. статья, коммент. Т.А. Кошемчук. - СПб: ЦСО. 800 с.

2- Волошин М. (1904). Магия творчества // «Весы», № 11.

3- Кошемчук Т.А. (1990). Сонеть Максимилиана Волошина // Дисс. к.ф.н. Тбилиси.

4- Кошемчук Т.А. (2006). Русская поэзия в контексте православной культуры. СПб: «Наука». 639c.

5- Кошемчук Т.А. (2009). Русская литература в православном контексте. СПб: «Наука». 278 с.

6- Кошемчук Т.А. (2015). ОТРЫВОЧНЫЕ ПРОЗРЕНИЯ. Статьи о русской литературе. ИЗ УВИДЕННОГО. Итальянские письма. - М-СПб: Центр гуманитарных инициатив. $268 \mathrm{c}$. 
7- Кошемчук Т.А. (2018). ПО КАНВЕ БОГОМЫСЛИЯ. Статьи о русской литературе. Максимилиан Волошин. Итальянский фрагмент. - М-СПб: РХГА. 213 c.

8- Кошемчук Т.А. (2020). СОЗЕРЦАНИЯ И ВСТРЕЧИ. Статьи о русской литературе. ИЗ УВИДЕННОГО. - СПб: Центр гуманитарных инициатив, 2020. $268 \mathrm{c}$.

9- Кошемчук Т.А. (2020а). СОЗЕРЦАНИЕ: в путешествиях И.А.Гончарова $и$ И.А.Бунина // СОЗЕРЦАНИЯ И ВСТРЕЧИ. Статьи о русской литературе. ИЗ УВИДЕННОГО. - СПб: Центр гуманитарных инициатив. С.4-34.

10- Кошемчук Т.А. (2020б). О культурологии Андрея Белого // Доклад на II Сурожских чтениях в Судаке 6-9 сентября 2020 года // Цит. по рукописи.

11- Прокофьев С.О. (2017). Максимилиан Волочин - человек, поэт, антропософ // Антология «M.A. Волошин: PRO ET CONTRA»// Составление, вступительная статья, комментарии Кошемчук Т.А. - СПб: ЦСО. С. 472-493.

12- Штейнер Рудольф (1991). Очерк тайноведения. - Ленинград: «ЭГО». 272 с.

\section{Bibliography}

1- Antologija «M.A.VOLOShIN: PRO ET CONTRA» (2017). (Lichnost' i idejnohudozhestvennoe nasledie M.A.Voloshina $\mathrm{v}$ ocenkah otechestvennyh pisatelej, myslitelej, issledovatelej) // Sost., vstup. stat'ja, komment. T.A. Koshemchuk. SPb: CSO. $800 \mathrm{~s}$.

2- Voloshin M. (1904). Magija tvorchestva // «Vesy», № 11.

3- Koshemchuk T.A. (1990). Sonety Maksimiliana Voloshina // Diss. k.f.n. - Tbilisi.

4- Koshemchuk T.A. (2006). Russkaja pojezija v kontekste pravoslavnoj kul'tury. $\mathrm{SPb}$ : «Nauka». 639s.

5- Koshemchuk T.A. (2009). Russkaja literatura v pravoslavnom kontekste. - SPb: «Nauka». $278 \mathrm{~s}$.

6- Koshemchuk T.A. (2015). OTRYVOChNYE PROZRENIJa. Stat'i o russkoj literature. IZ UVIDENNOGO. Ital'janskie pis'ma. - M - SPb: Centr gumanitarnyh iniciativ. 268s.

7- Koshemchuk T.A. (2018). PO KANVE BOGOMYSLIJa. Stat'i o russkoj literature. Maksimilian Voloshin. Ital'janskij fragment. - M - SPb: RHGA. $213 \mathrm{~s}$.

8- Koshemchuk T.A. (2020). SOZERCANIJa I VSTREChI. Stat'i o russkoj literature. IZ UVIDENNOGO. - SPb: Centr gumanitarnyh iniciativ, 2020. $268 \mathrm{~s}$.

9- Koshemchuk T.A. (2020a). SOZERCANIE: v puteshestvijah I.A.Goncharova $i$ I.A.Bunina // SOZERCANIJa I VSTREChI. Stat'i o russkoj literature. IZ UVIDENNOGO. - SPb: Centr gumanitarnyh iniciativ. S.4-34. 
10- Koshemchuk T.A. (2020b). O kul'turologii Andreja Belogo // Doklad na II Surozhskih chtenijah v Sudake 6-9 sentjabrja 2020 goda // Cit. po rukopisi.

11- Prokof'ev S.O. (2017). Maksimilian Voloshin - chelovek, pojet, antroposof // Antologija «M.A. Voloshin: PRO ET CONTRA» // Sostavlenie, vstupitel'naja stat'ja, kommentarii Koshemchuk T.A. - SPb: CSO. S. 472-493.

12- Shtejner Rudol'f (1991). Ocherk tajnovedenija. - Leningrad: «JeGO». 272 s.

\section{HOW TO CITE THIS ARTICLE}

Korneeva L. N. (2021). In The Hermeneutical Circle of an Itinerant Scientist. Issledovatel'skiy Zhurnal Russkogo Yazyka I Literatury, 9(2), 225-244.

DOI: $10.52547 /$ iarll.18.225

URL: https://www.journaliarll.ir/index.php/iarll/article/view/211 


\section{در حلقه هرمنوتيك دانشمند جهانكرد}

$$
\begin{aligned}
& \text { لودميلا نيكالايونا كارنيوا اق" } \\
& \text { شاعر و منتقد ادبى، دئَ } \\
& \text { جمهورى كريمه، روسيه. }
\end{aligned}
$$

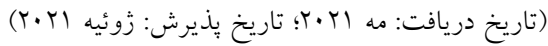

جكيده

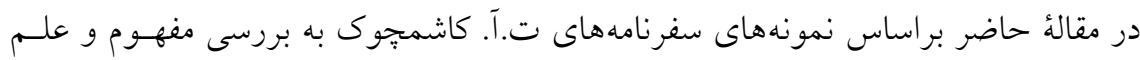

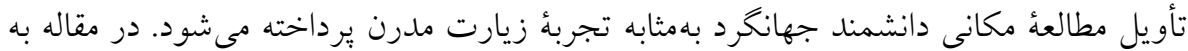

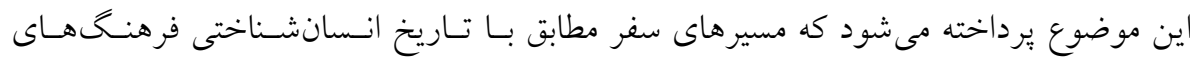

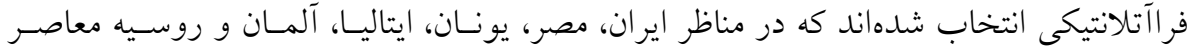

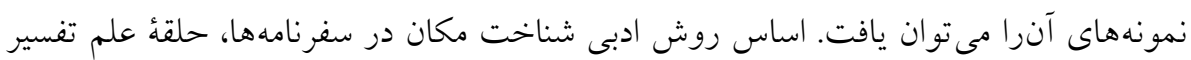

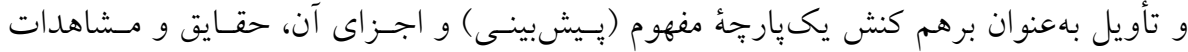

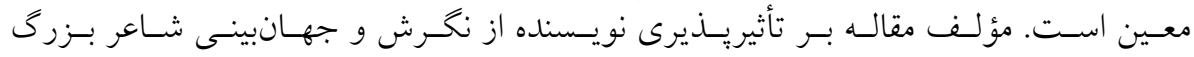

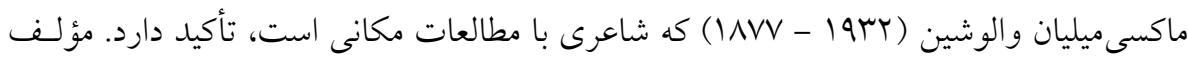

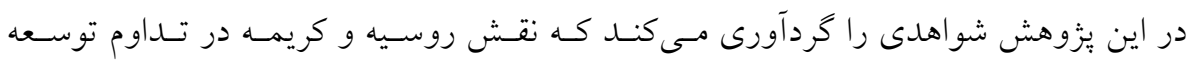

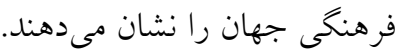

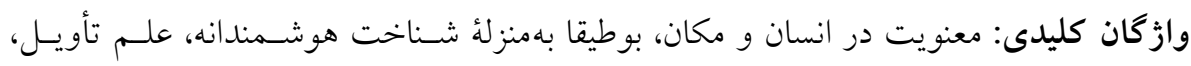

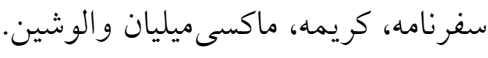

